\title{
New developments in the pathology of malignant lymphoma. A review of the literature published from August 2013 to December 2013
}

\author{
J. Han van Krieken
}

Published online: 30 January 2014

(C) Springer-Verlag Berlin Heidelberg 2014

\section{Introduction}

Although some writers stand behind their desk using pen and paper, most will do their work sitting on a chair looking at a screen. To sit too long and too often results in physical complaints and obesities, which we need to combat by doing regular exercise. Vermaete et al. (1) provide some relief to those who sit like me, looking at slides with lymphomas and writing about lymphomas and who are having too little exercise: at least it does not result in an increased risk to develop a lymphoma. Combining data from seven case-control studies and five cohort studies, they showed that no significant influence of lack of physical activity on risk of lymphoma development is present, neither for Hodgkin lymphoma nor for non-Hodgkin lymphoma. This gives me some confidence that writing this review at least does not lead to a lymphoma.

\section{Biology of lymphoma}

The journal Science indicated that immunotherapy is the most important scientific breakthrough from 2013. Indeed, we see a lot of new data arising in this area, and a prime example is targeting the programmed cell death ligand 1 (PD-L1) interaction in melanoma. Obviously, this pathway is analyzed in other malignancies too, and Chen et al. (2) find that PD-L1, an immunomodulatory molecule expressed by antigenpresenting cells, can be expressed not only by macrophages but also by Reed-Sternberg cells of different types of classical Hodgkin lymphoma (cHL) and malignant B cells in primary

J. H. van Krieken $(\bowtie)$

Department of Pathology, Radboud University Nijmegen Medical Centre, P.O. box 9101, 6500 HB Nijmegen, The Netherlands

e-mail: J.vankrieken@pathol.umcn.nl mediastinal large B cell lymphoma, T cell/histiocyte-rich B cell lymphoma, EBV-positive and EBV-negative posttransplant lymphoproliferative disorders (PTLD), EBVassociated diffuse large B cell lymphoma (DLBCL), plasmablastic lymphoma, and HHV8-associated primary effusion lymphoma. In contrast, neither the malignant nor the nonmalignant cells of nodular lymphocyte-predominant HL, DLBCL not otherwise specified, Burkitt lymphoma, and HHV8-associated Kaposi sarcoma expressed PD-L1. It might therefore be interesting to target PD-L1 also in some types of B cell lymphoma.

The important role of microRNAs (miR) in regulating gene expression is becoming more and more clear. Especially, since miR can be detected relatively easy in formalin fixed paraffin embedded (FFPE) tissue, there is a large amount of studies investigating miR expression in tumors (see also below in "Prognostic factors in lymphoma"). It was previously shown by Leucci et al. that miR deregulation might have the same effect as a MYC translocation (3). Jin et al. (4) show that mice with MYC amplification only develop lymphoma in case both alleles of miR-17 92 are intact and that B cell specific transgenic miR-17 92 mice develop lymphomas even without a MYC alteration. They further show that miR-17 92 drives lymphomagenesis by suppressing the expression of multiple negative regulators of the PI3K and NFKB pathways and by inhibiting the mitochondrial apoptosis pathway; chemical inhibition of either pathway reduced tumor size and prolonged the survival of lymphoma-bearing mice.

Based on expression, profiling DLBCL is now commonly divided into two groups with different outcomes: germinal center (GC)-derived DLBCL, driven by addiction to BCL6 and activated $B$ cell; (A) subtype, driven by nuclear factor $\kappa B$. In the GC subtype, deacetylation of BCL6 is required for its transcriptional repressor effects allowing for the oncogene to drive lymphomagenesis. Amengual et al. (5) treated DLBCL cell lines with pan-DAC inhibitors in combination with 
niacinamide, which produced synergistic cytotoxicity in GC and not in A subtypes. This combination also produced remissions in a spontaneous aggressive B cell lymphoma mouse model expressing BCL6. In a proof-of-principle clinical trial, $24 \%$ of patients with relapsed or refractory lymphoma attained a response to vorinostat and niacinamide, and $57 \%$ experienced disease stabilization. Pfeiffer et al. (6) looked also at the molecular mechanisms that drive the two subgroups of DLBCL. They determined the expression of the tumor suppressor phosphatase and tensin homolog (PTEN) in 248 primary DLBCL patient samples. There was loss of PTEN in $55 \%$ of the GCB-DLBCLs, whereas this abnormality was found in only $14 \%$ of A-DLBCL patient samples. In GCBDLBCL cellines and patient samples, loss of PTEN was correlated with activation of the PI3K/protein kinase B (AKT) pathway, whereas reexpression of PTEN induced cytotoxicity by inhibiting PI3K/AKT signaling and downregulation of the transcription factor MYC. Reexpression of MYC rescued GCB-DLBCL cells from PTEN-induced toxicity, identifying a regulatory mechanism of MYC expression in DLBCL. Pharmacologic PI3K inhibition resulted in toxicity selectively in PTEN-deficient GCB-DLBCL lines. These results indicate that PTEN loss defines a PI3K/AKT-dependent GCB-DLBCL subtype that is addicted to PI3K and MYC signaling and suggest that pharmacologic inhibition of PI3K might represent a promising therapeutic approach in these lymphomas. Both studies indicate that it does not suffice to subclassify DLBCL but that it is even more important to determine the altered molecular pathways that can be targeted by specific therapy.

It is still a puzzle why some translocations occur and others not. Chaumeil et al. (7) addressed this by analyzing the aberrant rearrangements that occur in ataxia telangiectasia, which are thought to occur due to lack of repair. They show that a defect in feedback control of RAG2 activity gives rise to bilocus breaks and damage on TCRa/d and IgH in the same $\mathrm{T}$ cell at the same developmental stage. Both the RAG2 Cterminus and ATM prevent bi-locus RAG-mediated cleavage through modulation of three-dimensional conformation and nuclear organization of the two loci, an important mechanism for protection of the genomic integrity.

Not only mouse models and cell line work lead to better understanding of lymphomas. Detailed knowledge of gene expression enables to map the pathways that are altered in human lymphoma samples. Kimura et al. (8) performed a clever gene expression analysis in 15 mantle cell lymphomas (MCL) of different stages of aggressiveness: in situ MCL, classical MCL, intermediate cases, and blastic MCL. To identify genes involved in initiation, they compared the tumor cells of MCL in situ $(n=4)$ with normal mantle zone B lymphocytes $(n=4)$; for genes contributing to transformation, they compared the different groups of MCL. A significant number of genes belonging to the Wnt signaling pathway were involved in initiation. Transformation was associated with genes of the p53 interaction network (CDC2, BIRC5, and FOXM1).

Although the use of combination antiviral therapy (HAAR T) in HIV-infected individuals reduces the occurrence of AIDS-related lymphomas, these are still common. Liapis et al. (9) studied the microenvironment of AIDS-related lymphomas that occurred before and after the introduction of HAART, divided them in EBV-positive and EBV-negative groups and compared them with regular DLBCL. Lymphomas in the HAART era had less aggressive morphology and better outcome; MYC rearrangements and EBV were much more common in AIDS-related DLBCL, and EBVpositive cases had increased numbers of vessels and cytotoxic T cells.

Classification of $\mathrm{T}$ cell lymphomas remains difficult since there is no underlying theory on which it is based. Grouping of $\mathrm{T}$ cell lymphomas with CD30 expression brings cases from different WHO-defined entities into one group. By doing so, Bisig et al. (10) found common expression profiles and immunophenotypes that differed from CD30 negative cases. This result is not surprising because CD30 is a molecule that is associated with activation of several molecular pathways. The suggestion from the authors is that two biological subgroups can be defined on CD30 expression; it is probably more important to look for CD30 expression because this might make the patient eligible for anti-CD30 therapy.

The study of McDonnell et al. (11) also uses expression profiling, and in addition, metabolomics profiling, to study the effect of the nucleophosmin-anaplastic lymphoma kinase (NPM-ALK), the neo-RNA formed by the chromosomal translocation which defines the entity ALK + anaplastic large cell lymphoma (ALCL). NPM-ALK induces a metabolic shift toward aerobic glycolysis, increased lactate production, and biomass production. The metabolic shift is mediated through ALK phosphorylation of the tumor-specific isoform of pyruvate kinase (PKM2), resulting in decreased enzymatic activity. Small molecule activation of PKM2 or expression of mutated PKM2 leads to reversal of the metabolic shift coincident with increased cell death and reduced tumor growth in an in vivo xenograft model.

\section{Epidemiology of lymphoma}

Collecting data from rare cases is an important approach to better understanding. Nowadays, many patients live with therapy-induced immunodeficiency and are at risk to develop lymphoma, especially EBV-associated lymphoproliferations. One of the rarer forms is the immune deficiency-associated cHL type. Loo et al. (12) collected 10 such cases. These cases were all patients with an autoimmune disease, and the patients had been treated with a variety of immunosuppressive agents. By 
definition, all the cases had the morphology and phenotype of cHL, and eight carried EBV in the tumor cells. All patients had a good outcome after discontinuation of the immunomodulatory drug and chemotherapy. It remains to be studied whether less aggressive therapy like in primary immune-deficiency might be effective as well.

Primary cutaneous marginal zone B cell lymphoma (cMZL) is a rare disease as well, but Servityje et al. (13) were able to collect 137 cases. In 121 of the patients $(88 \%)$, there was complete remission after initial treatment, but 53 patients (44\%) had a cutaneous relapse (median DFS was 47 months). Patients with multifocal lesions or T3 disease showed higher relapse rate and shorter DFS. Overall survival at 5 and 10 years was $93 \%$. Only six patients $(4 \%)$ developed extracutaneous disease during follow-up. The authors conclude that their results support long-term follow-up in patients with primary cMZL and that further investigation on systemic therapies in patients with disseminated skin lesions is needed. I would argue that an overall survival rate of $93 \%$ at 10 years implies that further improvement is hardly possible and that follow-up is really not needed, so that patients may truly feel cured.

Lymphomas have a variety of genetic alterations, and it is well known that $\mathrm{t}(14 ; 18)$-positive follicular lymphoma is rare in Asia but common in Europe and North America. Chen et al. (14) investigated the cytogenetic alterations in DLBCL in Chinese and American patients. Using interphase FISH to determine the presence of $\mathrm{t}(14 ; 18)$ and BCL6 and MYC rearrangements and immunohistochemistry to categorize the lymphomas into the GC- or A-DLBCL subtypes, they found that Chinese patients had more often BCL6 rearrangements and gains of $1 \mathrm{q}$ and $11 \mathrm{q}$ but lower incidence of the $t(14 ; 18)$ in GCB-DLBCL but not in A-DLBCL (although this conclusions by the authors is a bit strange: there was only one case of $t(14 ; 18)$ in the total group!). In A-DLBCL, both the Chinese and American patients had often gains of 3/3q and 18/18q. Although it is not mentioned in the abstract, an important difference was that in Chinese patients, only $25 \%$ of the cases was GCB-DLBCL; in the Americans, it was about $50 \%$. Given the imperfect way by which the Hans algorithm classifies A-DLBCL and GCB-DLBCL, an alternative interpretation could be that there are no differences in genetic alterations in lymphoma subtypes, but there are differences in incidence of lymphoma types between Chinese and American patients, which is well known for other lymphoma types.

Good databases are an endless source for epidemiological studies. Because treatment and outcome changes and improves over time, existing data need to be updated. Especially the introduction of rituximab has altered outcome so much that many articles have arisen that give important new data on outcome and prognostic factors (15-22). Link et al. (23) describe the clinical features of 631 patients with newly diagnosed grades 1 to 3 a follicular lymphoma (FL). At a median follow-up of 5 years, 79 patients had died, and in 60 patients, the lymphoma had transformed (10.7\%), leading to an estimated rate of $2 \%$ per year. There was more often transformation in patients who had initially no treatment than in patients who initially received rituximab monotherapy (14.4 versus $3.2 \%$ ). Median overall survival following transformation was 50 months and was higher in patients with a late transformation. These findings indicate that transformation of FL rates in the rituximab era are lower than reported in older series and that posttransformation prognosis is substantially better.

Lebwohl et al. (24) use their large database of patients with celiac disease (CD) and found that among 7,625 patients with $\mathrm{CD}, 3,308$ (43\%) had persistent villous atrophy in the followup biopsy, but data on dietary adherence were not available. To me, this is a very high number; very different from our own experience in which refractory celiac disease is rare (25). The overall risk for lymphoma was higher than that in the general population but only among patients with persistent villous atrophy and not in patients with mucosal healing. As expected, the risk to develop T cell lymphoma was increased, not B cell lymphoma.

\section{Defining entities}

\section{Hodgkin lymphoma}

Nathwani et al. (26) looked at 32 cases of nodular lymphocyte predominant Hodgkin lymphoma (NLPHL) from Finland for the presence of intranodular clusters of cytologically activated lymphoid cells producing a moth-eaten pattern. This pattern was present in all cases, but subtle in $62.5 \%$ and overt in $37.5 \%$. The cells in subtle clusters (20 cases) were very difficult to identify. The 12 cases with overt clusters had cells that were positive with CD3, CD4, PD1, CXCL13 (T follicular helper $[\mathrm{T}(\mathrm{FH})]$ phenotype), rarely expressed $\mathrm{Ki}-67$, and BCL2. Clinical presentation for all 32 Finnish patients was distinctive: $97 \%$ men, $97 \%$ with peripheral lymphadenopathy, and $35.5 \%$ with stage III/IV disease. Only $22 \%$ relapsed; $97 \%$ were in remission. There was no significant clinical difference between cases with overt and subtle clusters. The intranodular-activated TFH cells in NLPHL were not associated with adverse clinical outcome.

HL used to be diagnosed by morphology alone, which sometimes included a prolonged search. As Dennis Wright used to say: the longer you look for a Reed-Sternberg cell, the weaker the criteria will get. With immunohistochemistry, we do not need to look for these cells anymore, but I still like to see them and waste some time on the search. We have now a 
good panel that helps to identify HL, but some cases with abnormal staining pattern remain. According to Tang et al. (27), insulin-like growth factor II mRNA-binding protein 3 (IMP3) is a good marker for Hodgkin and Reed-Sternberg cells. IMP3 is ubiquitously expressed in embryos, mediating organogenesis, RNA trafficking, and cell growth, and is downregulated in adult tissue. IMP3 has recently been shown to be overexpressed in some malignant epithelial neoplasms and to be a useful diagnostic and/or prognostic biomarker for several carcinomas. They found expression in $80 / 81$ with $72.8 \%(59 / 81)$ of the tumors showing strong, diffuse cytoplasmic staining. This was more than CD30 (82.7\%, 67/81), CD15 (65.4 \%, 53/81), PAX5 (84.0 \%, 68/81), and MUM1 (85.2\%, 69/81). This is to me a worrying result: I find it extremely difficult to diagnose HL in case CD30 is negative. Since data on mimics of $\mathrm{HL}$ and other lymphomas are lacking, the conclusion by the authors that IMP3 may be a useful diagnostic marker of Hodgkin lymphoma, helping to improve diagnostic accuracy for this malignancy is not substantiated by the data.

\section{B cell lymphomas}

Extranodal marginal zone lymphomas (eMZL) have the unique feature that some of them are related to microorganisms. In a part of the ocular eMZL, Chlamydophila psittaci can be found, and antibiotics can cure these patients. Zhu et al. (28) looked at 45 cases without identifiable microorganisms for chromosomal translocations as well as CARD11, MYD88 (L265P), and A20 mutations/deletions. The translocations $\mathrm{t}(14 ; 18)(\mathrm{q} 32 ; \mathrm{q} 21)$ IGH-MALT1 and $\mathrm{t}(11 ; 18)(\mathrm{q} 21 ; \mathrm{q} 21)$ API2-MALT1 were not detected in any of the analyzed tumors, while three tumors harbored IGH translocations to an unidentified partner; also CARD11 mutations were not found, and the MYD88 L265P mutation was detected in three $(6.7 \%)$ tumors. A20 mutations and deletions were detected in seven (15.6\%) and six (13.3\%) tumors, respectively. Therefore, the observed genetic aberrations could account for the activation of the nuclear factor (NF)-kB signaling pathway in only a minority of the cases, which makes them distinct from other MZL.

An et al. (29) add another article to the series that exists on $\mathrm{t}(11$; 14) multiple myeloma (MM) because the data in the literature are so variable. In their 350 patients with various plasma cell malignancies, including newly diagnosed MM (NDMM, $n=253$ ), relapsed/refractory MM (RRMM, $n=77$ ), as well as primary and secondary plasma cell leukemia (PCL, $n=10$ and $n=10$, respectively), they found a remarkably higher frequency of $\mathrm{t}(11 ; 14)$ in the PCL than in the NDMM (in contrast to most literature, and it is well known that in MGUS, $t(11 ; 14)$ can be found). As it is well known, $t(11 ; 14)$ MM group was associated with a significantly higher positive rate of B-lineage-associated antigens CD20 and CD79a but also the lack of CD56 expression. Patients with $\mathrm{t}(11 ; 14)$ - positive NDMM had a comparable outcome as the negative cases. Patients receiving bortezomib-based treatment who had $\mathrm{t}(11 ; 14)$ positivity without CD20 expression had a significantly shortened PFS (11.0 versus 43.0 months, $p=0.005$ ) and OS ( 16.5 versus 54.0 months, $p=0.016)$ compared to patients with CD20 positive MM. However, the numbers are relatively small. It is doubtable that this article will settle the debate on the prognostic and/or predictive impact of $\mathrm{t}(11 ; 14)$ in MM.

\section{$\mathrm{T}$ cell lymphomas}

The classification of peripheral T cell lymphomas (PTCLs; ie, PTCL not otherwise specified [NOS], angioimmunoblastic T cell lymphoma [AITL], and anaplastic large-cell lymphoma [ALCL]) is difficult, because morphologic and phenotypic features are overlapping. Piccaluga et al. (30) studied 244 PTCLs, including 158 PTCLs NOS, 63 AITLs, and 23 ALK-negative ALCLs by gene expression profiling. After profile discovery in a training set, they were able to separate very well AITL and ALK-negative ALCL from PTCL NOS with overall accuracy of $77 \%$ for AITL and $93 \%$ for ALKnegative ALCL. The classifier predicted outcome better than the pathological classification. The authors conclude that the usage of their approach can be used as additional tool in the diagnostic workup of nodal PTCL. If they had been really confident in their data, the conclusions should have been that they found a molecular classifier that is better than the (as the authors state) poorly reproducible WHO classification for T cell lymphomas and therefore should replace expert pathologist classification.

Liu et al. (31) used miR profiling to find differences between 33 ALK positive and 25 negative ALCL, 9 AILT, 11 PTCL-NOS, and normal T cells. ALCLs express many of the miRNAs that are highly expressed in normal $\mathrm{T}$ cells with the prominent exception of miR-146a. Unsupervised hierarchical clustering demonstrated distinct clustering of ALCL, PTCLNOS, and the AITL subtype of PTCL. Cases of ALK+ ALCL and ALK- ALCL were interspersed in unsupervised analysis, suggesting a close relationship at the molecular level. They furthermore identified an miRNA signature of seven miRNAs (5 upregulated: miR-512-3p, miR-886-5p, miR-886-3p, miR708, miR-135b; 2 downregulated: miR-146a, miR-155) associated with ALK + ALCL cases. Finally, an 11-miRNA signature (4 upregulated: miR-210, miR-197, miR-191, and miR512-3p; 7 downregulated: miR-451, miR-146a, miR-22, miR455-3p, miR-455-5p, miR-143, and miR-494) differentiates ALK- ALCL from other PTCLs. Whether this classifier may outperform routine classification remains to be tested.

\section{Cutaneous lymphomas}

IgG4 disease remains a hot topic. Brenner et al. (32) investigated MZL for IgG4 expression because, in their words, it was 
only partially studied. They collected a series of 169 MZL that had clear plasmacytic differentiation, including 49 primary cutaneous (c) MZL. From the 20 IgG4-positive cases, 19 were cMZL, being $39 \%$ of the cMZLs. None of the patients had preexisting IgG4 disease, and there were no morphological or phenotypical differences with $\mathrm{IgG} 4$ negative cases. Nevertheless, in case $\operatorname{IgG} 4$ expression is found in a B cell lymphoma in the skin, it is likely that it is a cMZL.

\section{New entities/subtypes}

Mollejo et al. (33) collected cases of lymphoproliferation in patients with hepatitis $\mathrm{C}$. They found that not only splenic marginal zone lymphoma, follicular lymphoma, and diffuse large B cell lymphoma ca be associated with hepatitis $\mathrm{C}$ but also two poorly described groups of cases. The first group consisted of disseminated MZL without splenic MZL features; the other consisted of monoclonal B lymphocytes in the peripheral blood, bone marrow or other tissues, with no clinical or histological evidence of lymphoma.

BCL2 negative follicular lymphoma remains intriguing and may actually often be nodal (N) MZL (34). Adam et al. (35) collected $22 \mathrm{FL}$ (out of 240 cases) that were negative with the standard BCL2 antibody. We have previously shown that in case there is a BCL2 chromosomal break, alternative antibodies will stain the lymphoma cells (36), which was confirmed in this study: 11 of the 12 cases with a BCL2 break were positive with an alternative BCL2 antibody. The 10 cases that were negative for a chromosomal break in the BCL2 locus did not stain for any BCL2 antibody, 2 had a BCL6 break and 6 were CD10 negative. Although the authors conclude that this is a special subgroup of FL, the data actually fit well with the idea that these cases represent NMZL.

Recent reports indicate that small intestinal $\mathrm{T}$ cell lymphoproliferations seen in the setting of celiac disease are not always aggressive enteropathy-associated $\mathrm{T}$ cell lymphomas (EATL). Margolskee et al. (37) describe three cases of indolent small intestinal CD4+ T cell lymphomas in refractory celiac disease patients. All patients presented with diarrhea and weight loss, and small intestinal biopsies showed crypt hyperplasia, villous atrophy, and a dense lamina propria infiltrate of small-sized CD4+ T cells often with CD7 downregulation or loss. Gastric and colonic involvement was detected in two of the three patients. Persistent, clonal TCR $\beta$ gene rearrangement products were detected at multiple sites. Two patients are alive, with persistent disease (4.6 and 2.5 years postdiagnosis) despite immunomodulatory therapy; one patient died due to bowel perforation related to large cell transformation 11 years after the diagnosis. Another indolent PTCL is described by Hayashi et al. (38). Of their 277 PTCL-NOS cases, 10 were T cell lymphomas composed of clonal small-sized cells with slight nuclear atypia and few mitosis and low Ki67. All were CD3 positive and remarkably five were also CD20. Eight of the patients had extranodal involvement (5 patients, spleen; 3 patients, thyroid), and five patients were at clinical stages I or II. Five patients received chemotherapy, whereas for three patients, treatment consisted only of observation following surgical resection of the spleen or thyroid. Nine patients were alive at a median follow-up time of 19.5 months, whereas one patient died of an unrelated disease. The present study strongly indicates that $\mathrm{T}$ cell lymphoma with small-sized lymphoma cells and a low Ki-67 labeling index is a distinct variant. The authors conclude that recognition of this lymphoma subtype, which may have a benign clinical course, seems important. Alternatively, one may wonder whether the clonality testing was important in the diagnosis in both studies of Margolskee and of Hayashi and that the fact that clonal $\mathrm{T}$ cell proliferations at extranodal sites may be due to a restricted repertoire was not recognized (39). More indicative than clonality alone of a malignant disease are chromosomal rearrangements. In the spectrum of cutaneous T cell lymphoproliferations, it is difficult to predict the clinical course based on histology alone. Karai et al. (40) describe 11 cutaneous lymphoproliferative lesions with morphological malignant features but benign clinical course like in lymphomatoid papulosis. These cases were distinctive in that there was a chromosomal rearrangement of the DUSP22IRF4 locus on 6p25.3. All patients were older adults (67 to 88 years) with predominantly localized lesions and clinical presentations suggesting benign inflammatory dermatoses or low-grade epithelial tumors. The lesions showed a biphasic growth pattern, with small cerebriform lymphocytes in the epidermis and larger transformed lymphocytes in the dermis. No patient developed disseminated skin disease or extracutaneous spread, and untreated lesions regressed spontaneously. The findings emphasize the importance of combining clinical and pathological features in the diagnosis of cutaneous lymphoproliferative disorders.

\section{Pitfalls in lymphoma diagnosis}

The interest in the reliability of pathological diagnosis had increased due the relevance of a correct diagnosis now that there is an increasing number of therapeutical options. Chang et al. (41) reviewed 406 cases in Taiwan and found major differences in $222(55 \%)$ of the cases including $32(14 \%)$ changes from malignant to benign disease. The authors suggest that the limited use of ancillary techniques by general pathologists is an important reason for discrepancy. This discrepancy rate is much higher than the other found in a recent study from the Netherlands, although also in that study, still almost $10 \%$ major discrepancies were found (42). It is clear that special expertise is needed for correct diagnosis and classification of lymphomas, but even then, there are 
important issues like the distinction between FL and NMZL (see above). Dyhdalo et al. (43) looked carefully at the patterns of the staining of germinal center cell markers CD10, BCL6, and LMO2. Forty-two cases of MZL involving lymph nodes and 88 cases of FL were examined, and they found commonly interfollicular staining for GC markers in FL but rarely in MZL, including BCL2-positive and BCL2-negative cases. Furthermore, atypical patterns of intrafollicular GC staining were more common in MZL than in FL. Nevertheless, a positive marker for NMZL would be extremely helpful for their recognition. Bob et al. (44) investigated 60 nodal lesions with marginal zone and monocytoid B cells on the expression of IRTA 1 and T-bet, markers that stain marginal zone cells. Remarkably, the cases were divided into malignant and benign based on light chain restriction and clonality testing, and subsequently, architectural features were analyzed. Generally, this is done in the reverse order, but actually, the result is the same: all non-clonal lesions were architecturally benign. More important was the staining with IRTA1 and T-bet. These markers stained all reactive cells and $90 \%$ of the malignant cases. Specificity was not studied since no other lymphoma types were involved in this study.

\section{Prognostic factors in lymphoma}

Several journals have now debates on the progress of science, and especially, the amount of money that goes into studies on prognostic markers is mentioned as a waste of time and money. I have already pointed out in previous reviews of the literature that predictive studies are more important than prognostic ones, since the latter are very rarely used in routine practice, but also in this review, most cited articles deal with prognostic factors. Should I stop quoting them? Not yet, I think. Even though I do think that it is unlikely that any of the following markers will ever be used in routine practice, the data may still lead to better understanding. Although I agree with the complaint that scientists nowadays write so much that they do not have the time to read, this is certainly not the case for most readers of the Journal of Hematopathology. So in brief, a series of prognostic studies but first a predictive one.

Narayan et al. (45) found promoter hypermethylation of the PCDH10 gene in 57 to $100 \%$ of both primary B and T cell lymphoma specimens and cell lines but also in $29 \%$ of cases of reactive follicular hyperplasia. Both T and B cell lymphoma cell lines with methylation-mediated inactivation of PCDH10 were resistant to doxorubicin treatment, suggesting that hypermethylation of this gene might predict absence of chemotherapy response.

Koh et al. (46) looked for prognostic factors in the microenvironment of cHL and focused on angiogenesis. They investigated 167 cases of $\mathrm{cHL}$ and found that COX-2 expression was associated with a lower overall survival rate and high
MVD with a lower event-free survival rate. Reporting two different outcome values already suggest that significant associations were sought for, rather than have a hypothesis drive the statistical evaluation. Furthermore, COX-2 and VEGF expression correlated with angiogenesis and tumor progression. The authors suggest that their findings support targeting COX-2 as a potential new therapeutic approach in cHL. This is a very common mistake, thinking that a factor that is prognostically relevant therefore is a good target for treatment.

Single nucleotide polymorphisms (SNP) indicate differences in gene function and may occur in miRs. Navarro et al. (47) looked for eight such SNP and miRs in $148 \mathrm{cHL}$ samples and found that this approach can add useful prognostic information on treatment-related toxicity and clinical outcome in Hodgkin lymphoma and can be used to identify patients likely to be chemoresistant or to relapse.

Grading of FL remains a source of dispute, being not too reproducible. Wahlin et al. (48) graded FL in cases that were treated in two clinical trials using rituximab as monotherapy, and the results in both were the same, strengthening the results. Higher grades correlated with better treatment response and a longer time to the next treatment. They conclude that WHO grade 1 follicular lymphoma correlates with inferior outcome in patients who receive rituximab monotherapy. Maeshima et al. (49) confirmed the findings in an independent study. Similarly, Frei et al. (17) found that the prognostic impact of cyclin E expression in DLBCL disappeared in case rituximab is given. These results stress that prognostic factors need to be reinvestigated when new treatments are used (see above).

Hother et al. (50) investigated by miR profiling the mechanism that leads to aggressive lymphoma in ocular adnexal B cell lymphoma. They had a remarkable large number of DLBCL in that site $(n=25)$ and compared these with 18 MZL (I have seen many cases of low-grade lymphoma at that site but very rarely a DLBCL). They conclude that there is more activation of the MYC and NFKB pathway in the aggressive lesions but also that some DLBCL had a profile that was similar to EMZL. miR was also assessed in cHL. Sanchez-Espitidion et al. (51) did global miR expression profiling on 29 advanced cHL patients and created a cHLmiR signature with 234 miRNAs differentially expressed. A subset of these miRs was associated with outcome and selected for study in an independent set of $168 \mathrm{cHL}$ samples using quantitative reverse transcription polymerase chain reaction. A miR signature with miR21, miR30E, miR30D, and miR92B identified two risk groups with significant differences in 5-year FFS (81 \% versus $35.7 \%$ ). Functional silencing of miR21 and miR30D in L428 cells showed increased sensitivity to doxorubicin-induced apoptosis. Also, this study therefore is a bit strange mix between drug target discovery and prognostic marker evaluation. Navarro et al. (52) used a similar approach in mantle cell lymphoma (MCL) and found 
in 30 leukemic MCLs a classifier that was confirmed in 29 other leukemic MCLs and 50 nodal MCLs. They came up with two groups that differed in immunoglobulin heavy chain mutational status, SOX11 expression, nodal presentation, and outcome. Goswani et al. (53) also used miR profiling in MCL with a training set of 119 cases and a validation set of 114 cases. They found $11 \mathrm{miRs}$ differentially expressed between indolent and aggressive cases and two that indicated worse prognosis. Together with the Ki67 score, they created a prognostic model. Enjuanes et al. (54) used another profiling approach, namely genome-wide methylation, and identified a subset of MCL with high $\mathrm{CpG}$ methylation, which was correlated with the proliferation index and poor prognosis. However, even the well defined and validated, easy to apply biomarker $\mathrm{Ki} 67$ index is presently not in routine use $(55,56)$.

Although there are good prognostic criteria in Mycosis fungoides for many years, Benton et al. (57) start their article with the statement, "There is no prognostic index for primary cutaneous T-cell lymphomas such as mycosis fungoides (MF) and Sezary syndrome (SS)." Using a multivariate analysis on 1,502 patients with external validation on 1,221 patients, they constructed two separate models each defined using three distinct groups for low and high stage patients: 0-1 (low risk), 2 (intermediate risk), and 3-5 factors (high risk). Ten-year OS in the early stage model was $90.3 \%$ (low), $76.2 \%$ (intermediate), and $48.9 \%$ (high), and for the late stage model, $53.2 \%$ (low), $19.8 \%$ (intermediate), and $15.0 \%$ (high). For the validation set, significant differences in OS and PFS in early stage patients were also noted. In late stage patients, only OS differed between the groups. Since the article combines different stages into only low and high stage, it is difficult to assess the additional value above classic staging.

\section{Staging}

Especially, PET-imaging may become an important tool in staging lymphomas, since it gives an overview over the total body and may have less sampling error than bone marrow biopsies (BMB). According to Khan (58), PET-scanning identifies indeed more bone marrow positive patients in DLBCL staging (33 compared to 14 out of 130 patients). PET identified all clinically important marrow lymphoma localizations, while biopsy did not upstage any patient. As a secondary aim, they compared the prognosis of marrow involvement, as detected by PET-CT or biopsy. Cases with marrow deposits identified by PET-CT but not by biopsy had progression-free survival and overall survival similar to stage IV disease without involved marrow. This is in accordance with data from a study by Cortes-Romera (59) on 84 patients with DLBCL and 63 with HL in whom bone marrow infiltration was detected by PET/CT in 39 (26\%) and by BMB in 21 (14\%) cases. Discordant results were observed in 19 patients (14\%); 18 of them with positive PET/CT and negative standard BMB results. However, this study did not have clinical outcome data. The third study (60) on 133 patients with DLBCL with a similar approach has also similar findings: 8 were positive according to the biopsy and 32 were positive with PET/CT. Twenty-nine patients $(22 \%)$ experienced recurrence or disease progression during follow-up, and 20 patients died (15\%). In multivariate analysis, only the International Prognostic Index and the PET/CT bone marrow status were independent predictors of progression-free survival, but only the International Prognostic Index remained an independent predictor of overall survival.

Moon et al. (61) performed a staging study in nasal type natural killer/T cell lymphoma in 52 consecutive patients with nasal-type NK/T cell lymphoma. Of the 59 nodal and 71 extranodal anatomic regions that were truly positive for malignancy (18), F-FDG PET/CT detected 58 nodal and 69 extranodal. PET/CT findings altered the original staging category for 12 patients $(21.2 \%)$ and affected treatment planning in 23 cases $(44.2 \%)$.

\section{Ancillary techniques}

Munoz-Marmol et al. (62) addressed the important issue of FISH-probe selection for determination of MYC status in B cell lymphomas in 91 aggressive B cell lymphomas. Detection of the MYC break in cases with IgH-MYC translocation was not a problem (13/13 detected with all 3 commercial probes, 2 break-apart, 1 fusion), but 7/13 non-IgH-MYC translocations were detected by only one of the break-apart probes, and MYC amplification was seen by the fusion probe as translocation. There is urgent need for a consensus guideline on this topic. Alternatively, MYC can be assessed by immunohistochemistry, but this does not give the same results as FISH testing. Oberly et al. (63) look with immunohistochemistry at MYC expression in a tissue microarray containing $62 \mathrm{MCLs}$ and 29 controls. MYC IHC scores correlated with MYC RNA expression and weakly with $\mathrm{Ki} 67$ proliferation index. None of the 57 cases assessed, including all of the blastic cases, showed MYC rearrangement by fluorescence in situ hybridization. The MYC IHC score was an independent predictor of progression-free survival and overall survival.

In this time of doubt on scientific results, it is important that data from the literature are repeated and strengthened. Hartman et al. (64) undertook such a study by doing clonality testing on a large number of lymphomas and reactive lesions, thus repeating with much larger numbers the data from the Biomed 2 consortium on clonality testing (65-67). They confirmed previously published clonality rates in various $\mathrm{B}$ cell, $\mathrm{T}$ cell, and Hodgkin lymphoma cases; that in reactive lesions clonality can be present for the IGH locus but frequently accompanied by additional polyclonal background 
that clonality for TCRG can found in some diffuse large B cell lymphomas. However, a new finding is that seven of the latter cases appeared to have arisen from an underlying peripheral $\mathrm{T}$ cell lymphoma. Finally, five cases with monoclonal TCRG rearrangements, originally diagnosed as Hodgkin lymphomas, were reclassified as $\mathrm{T}$ cell lymphomas.

Geurts-Giele et al. (68) claim that successive B cell lymphomas mostly reflect recurrences rather than unrelated primary lymphomas. They base their argument on a study in 36 patients with a second lesion after a first diagnosis of lymphoma. Based on clonality testing, they found that there were 30 recurrences, 2 possible recurrences, 2 different clones with a common origin, and 2 unrelated primary lymphomas.

West et al. (69) looked at two FL patients who developed Langerhans cell histiocytosis with clonality testing and claim that the two lesions have a clonal relationship. B cell clonality is not so convincing since only a few FL cells gives rise to a clonal result, but FISH for translocations is more convincing. These data suggest that enormous transdifferentiation may happen, which is actually a blow to the basis of our classification system.

\section{References}

1. Vermaete NV, Wolter P, Verhoef GE, Kollen BJ, Kwakkel G, Schepers L, Gosselink R (2013) Physical activity and risk of lymphoma: a meta-analysis. Cancer Epidemiol Biomarkers Prev 22: 1173-1184

2. Chen BJ, Chapuy B, Ouyang J, Sun HH, Roemer MG, Xu ML, Yu H, Fletcher CD, Freeman GJ, Shipp MA, Rodig SJ (2013) PD-L1 expression is characteristic of a subset of aggressive B-cell lymphomas and virus-associated malignancies. Clin Cancer Res 19:34623473

3. Leucci E, Cocco M, Onnis A, De Falco G, van Cleef P, Bellan C, van Rijk A, Nyagol J, Byakika B, Lazzi S, Tosi P, van Krieken H, Leoncini L (2008) MYC translocation-negative classical Burkitt lymphoma cases: an alternative pathogenetic mechanism involving miRNA deregulation. J Pathol 216:440-450

4. Jin HY, Oda H, Lai M, Skalsky RL, Bethel K, Shepherd J, Kang SG, Liu WH, Sabouri-Ghomi M, Cullen BR, Rajewsky K, Xiao C (2013) MicroRNA-17 92 plays a causative role in lymphomagenesis by coordinating multiple oncogenic pathways. EMBO J 32:2377-2391

5. Amengual JE, Clark-Garvey S, Kalac M, Scotto L, Marchi E, Neylon E, Johannet P, Wei Y, Zain J, O'Connor OA (2013) Sirtuin and panclass I/II deacetylase (DAC) inhibition is synergistic in preclinical models and clinical studies of lymphoma. Blood 122:2104-2113

6. Pfeifer M, Grau M, Lenze D, Wenzel SS, Wolf A, Wollert-Wulf B, Dietze K, Nogai H, Storek B, Madle H, Dörken B, Janz M, Dirnhofer S, Lenz P, Hummel M, Tzankov A, Lenz G (2013) PTEN loss defines a PI3K/AKT pathway-dependent germinal center subtype of diffuse large B-cell lymphoma. Proc Natl Acad Sci U S A 110:12420-12425

7. Chaumeil J, Micsinai M, Ntziachristos P, Roth DB, Aifantis I, Kluger Y, Deriano L, Skok JA (2013) The RAG2 C-terminus and ATM protect genome integrity by controlling antigen receptor gene cleavage. Nat Commun 4:2231

8. Kimura Y, Arakawa F, Kiyasu J, Miyoshi H, Yoshida M, Ichikawa A, Niino D, Sugita Y, Okamura T, Doi A, Yasuda K, Tashiro K, Kuhara
S, Ohshima K (2013) The Wnt signaling pathway and mitotic regulators in the initiation and evolution of mantle cell lymphoma: gene expression analysis. Int J Oncol 43:457-468

9. Liapis K, Clear A, Owen A, Coutinho R, Greaves P, Lee AM, Montoto S, Calaminici M, Gribben JG (2013) The microenvironment of AIDS-related diffuse large B-cell lymphoma provides insight into the pathophysiology and indicates possible therapeutic strategies. Blood 122:424-433

10. Bisig B, de Reyniès A, Bonnet $C$, Sujobert $P$, Rickman DS, Marafioti T, Delsol G, Lamant L, Gaulard P, de Leval L (2013) CD30-positive peripheral T-cell lymphomas share molecular and phenotypic features. Haematologica 98:1250-1258

11. McDonnell SR, Hwang SR, Rolland D, Murga-Zamalloa C, Basrur V, Conlon KP, Fermin D, Wolfe T, Raskind A, Ruan C, Jiang JK, Thomas CJ, Hogaboam CM, Burant CF, Elenitoba-Johnson KS, Lim MS (2013) Integrated phosphoproteomic and metabolomics profiling reveals NPM-ALK-mediated phosphorylation of PKM2 and metabolic reprogramming in anaplastic large cell lymphoma. Blood 122:958-968

12. Loo EY, Medeiros LJ, Aladily TN, Hoehn D, Kanagal-Shamanna R, Young KH, Lin P, Bueso-Ramos CE, Manning JT Jr, Patel K, Thomazy V, Brynes RK, Goswami M, Fayad LE, Miranda RN (2013) Classical Hodgkin lymphoma arising in the setting of iatrogenic immunodeficiency: a clinicopathologic study of 10 cases. Am J Surg Pathol 37:1290-1297

13. Servitje O, Muniesa C, Benavente Y, Monsálvez V, Garcia-Muret MP, Gallardo F, Domingo-Domenech E, Lucas A, Climent F, Rodriguez-Peralto JL, Ortiz-Romero PL, Sandoval J, Pujol RM, Estrach MT (2013) Primary cutaneous marginal zone B-cell lymphoma: response to treatment and disease-free survival in a series of 137 patients. J Am Acad Dermatol 69:357-365

14. Chen Y, Dave BJ, Zhu X, Chan WC, Iqbal J, Sanger WG, Fu K (2013) Differences in the cytogenetic alteration profiles of diffuse large B-cell lymphoma among Chinese and American patients. Canc Genet 206:183-190

15. Tzankov A, Xu-Monette ZY, Gerhard M, Visco C, Dirnhofer S, Gisin N, Dybkaer K, Orazi A, Bhagat G, Richards KL, Hsi ED, Choi WW, van Krieken JH, Ponzoni M, Ferreri AJ, Ye Q, Winter JN, Farnen JP, Piris MA, Møller MB, You MJ, McDonnell T, Medeiros LJ, Young KH (2013) Rearrangements of MYC gene facilitate risk stratification in diffuse large B-cell lymphoma patients treated with rituximabCHOP. Mod Pathol. doi:10.1038/modpathol.2013.214

16. Xu-Monette ZY, Møller MB, Tzankov A, Montes-Moreno S, Hu W, Manyam GC, Kristensen L, Fan L, Visco C, Dybkaer K, Chiu A, Tam W, Zu Y, Bhagat G, Richards KL, Hsi ED, Choi WW, van Krieken JH, Huang Q, Huh J, Ai W, Ponzoni M, Ferreri AJ, Wu L, Zhao X, Bueso-Ramos CE, Wang SA, Go RS, Li Y, Winter JN, Piris MA, Medeiros LJ, Young KH (2013) MDM2 phenotypic and genotypic profiling, respective to TP53 genetic status, in diffuse large Bcell lymphoma patients treated with rituximab-CHOP immunochemotherapy: a report from the International DLBCL Rituximab-CHOP Consortium Program. Blood 122:2630-2640

17. Frei E, Visco C, Xu-Monette ZY, Dirnhofer S, Dybkær K, Orazi A, Bhagat G, Hsi ED, van Krieken JH, Ponzoni M, Go RS, Piris MA, Møller MB, Young KH, Tzankov A (2013) Addition of rituximab to chemotherapy overcomes the negative prognostic impact of cyclin $\mathrm{E}$ expression in diffuse large B-cell lymphoma. J Clin Pathol 66:956961

18. Li Y, Gordon MW, Xu-Monette ZY, Visco C, Tzankov A, Zou D, Qiu L, Montes-Moreno S, Dybkaer K, Orazi A, Zu Y, Bhagat G, Richards KL, Hsi ED, Choi WW, van Krieken JH, Huang Q, Ai W, Ponzoni M, Ferreri AJ, Winter JN, Go RS, Piris MA, Møller MB, Wu L, Wang M, Ramos KS, Medeiros LJ, Young KH (2013) Single nucleotide variation in the TP53 3' untranslated region in diffuse large B-cell lymphoma treated with rituximab-CHOP: a report from the International DLBCL Rituximab-CHOP Consortium Program. Blood 121:4529-4540 
19. Hu S, Xu-Monette ZY, Tzankov A, Green T, Wu L, Balasubramanyam A, Liu WM, Visco C, Li Y, Miranda RN, Montes-Moreno S, Dybkaer K, Chiu A, Orazi A, Zu Y, Bhagat G, Richards KL, Hsi ED, Choi WW, Zhao X, van Krieken JH, Huang Q, Huh J, Ai W, Ponzoni M, Ferreri AJ, Zhou F, Slack GW, Gascoyne RD, Tu M, Variakojis D, Chen W, Go RS, Piris MA, Møller MB, Medeiros LJ, Young KH (2013) MYC/BCL2 protein coexpression contributes to the inferior survival of activated B-cell subtype of diffuse large B-cell lymphoma and demonstrates high-risk gene expression signatures: a report from The International DLBCL Rituximab-CHOP Consortium Program. Blood 121:4021-4031

20. Xu-Monette ZY, Wu L, Visco C, Tai YC, Tzankov A, Liu WM, Montes-Moreno S, Dybkaer K, Chiu A, Orazi A, Zu Y, Bhagat G, Richards KL, Hsi ED, Zhao XF, Choi WW, Zhao X, van Krieken JH, Huang Q, Huh J, Ai W, Ponzoni M, Ferreri AJ, Zhou F, Kahl BS, Winter JN, Xu W, Li J, Go RS, Li Y, Piris MA, Møller MB, Miranda RN, Abruzzo LV, Medeiros LJ, Young KH (2012) Mutational profile and prognostic significance of TP53 in diffuse large B-cell lymphoma patients treated with R-CHOP: report from an International DLBCL Rituximab-CHOP Consortium Program study. Blood 120: 3986-3996

21. Visco C, Tzankov A, Xu-Monette ZY, Miranda RN, Tai YC, Li Y, Liu WM, d'Amore ES, Li Y, Montes-Moreno S, Dybkaer K, Chiu A, Orazi A, Zu Y, Bhagat G, Wang HY, Dunphy CH, His ED, Zhao XF, Choi WW, Zhao X, van Krieken JH, Huang Q, Ai W, O'Neill S, Ponzoni M, Ferreri AJ, Kahl BS, Winter JN, Go RS, Dirnhofer S, Piris MA, Møller MB, Wu L, Medeiros LJ, Young KH (2013) Patients with diffuse large B-cell lymphoma of germinal center origin with BCL2 translocations have poor outcome, irrespective of MYC status: a report from an International DLBCL rituximab-CHOP Consortium Program study. Haematologica 98:255-263

22. Visco C, Li Y, Xu-Monette ZY, Miranda RN, Green TM, Li Y, Tzankov A, Wen W, Liu WM, Kahl BS, d'Amore ES, MontesMoreno S, Dybkaer K, Chiu A, Tam W, Orazi A, Zu Y, Bhagat G, Winter JN, Wang HY, O'Neill S, Dunphy CH, Hsi ED, Zhao XF, Go RS, Choi WW, Zhou F, Czader M, Tong J, Zhao X, van Krieken JH, Huang Q, Ai W, Etzell J, Ponzoni M, Ferreri AJ, Piris MA, Møller MB, Bueso-Ramos CE, Medeiros LJ, Wu L, Young KH (2012) Comprehensive gene expression profiling and immunohistochemical studies support application of immunophenotypic algorithm for molecular subtype classification in diffuse large B-cell lymphoma: a report from the International DLBCL Rituximab-CHOP Consortium Program study. Leukemia 26:2103-2113

23. Link BK, Maurer MJ, Nowakowski GS, Ansell SM, Macon WR, Syrbu SI, Slager SL, Thompson CA, Inwards DJ, Johnston PB, Colgan JP, Witzig TE, Habermann TM, Cerhan JR (2013) Rates and outcomes of follicular lymphoma transformation in the immunochemotherapy era: a report from the University of Iowa/MayoClinic Specialized Program of Research Excellence Molecular Epidemiology Resource. J Clin Oncol 31(26):3272-3286

24. Lebwohl B, Granath F, Ekbom A, Smedby KE, Murray JA, Neugut AI, Green PH, Ludvigsson JF (2013) Mucosal healing and risk for lymphoproliferative malignancy in celiac disease: a population-based cohort study. Ann Intern Med 159(3):169-175

25. Goerres MS, Meijer JW, Wahab PJ, Kerckhaert JA, Groenen PJ, Van Krieken JH, Mulder CJ (2003) Azathioprine and prednisone combination therapy in refractory coeliac disease. Aliment Pharmacol Ther 18:487-494

26. Nathwani BN, Vornanen M, Winkelmann R, Kansal R, Doering C, Hartmann S, Hansmann ML (2013) Intranodular clusters of activated cells with $\mathrm{T}$ follicular helper phenotype in nodular lymphocyte predominant Hodgkin lymphoma: a pilot study of 32 cases from Finland. Hum Pathol 44:1737-1746

27. Tang H, Wei Q, Ge J, Jian W, Liu J, Zhong L, Fu B, Zhao T (2013) IMP3 as a supplemental diagnostic marker for Hodgkin lymphoma. Hum Pathol 44:2167-2172
28. Zhu D, Ikpatt OF, Dubovy SR, Lossos C, Natkunam Y, ChapmanFredricks JR, Fan YS, Lossos IS (2013) Molecular and genomic aberrations in Chlamydophila psittaci negative ocular adnexal marginal zone lymphomas. Am J Hematol 88:730-735

29. An G, Xu Y, Shi L, Zou D, Deng S, Sui W, Xie Z, Hao M, Chang H, Qiu L $(2013) \mathrm{t}(11 ; 14)$ multiple myeloma: a subtype associated with distinct immunological features, immunophenotypic characteristics but divergent outcome. Leuk Res 37:1251-1257

30. Piccaluga PP, Fuligni F, De Leo A, Bertuzzi C, Rossi M, Bacci F, Sabattini E, Agostinelli C, Gazzola A, Laginestra MA, Mannu C, Sapienza MR, Hartmann S, Hansmann ML, Piva R, Iqbal J, Chan JC, Weisenburger D, Vose JM, Bellei M, Federico M, Inghirami G, Zinzani PL, Pileri SA (2013) Molecular profiling improves classification and prognostication of nodal peripheral T-cell lymphomas: results of a phase III diagnostic accuracy study. J Clin Oncol 31:3019-3025

31. Liu C, Iqbal J, Teruya-Feldstein J, Shen Y, Dabrowska MJ, Dybkaer K, Lim MS, Piva R, Barreca A, Pellegrino E, Spaccarotella E, Lachel CM, Kucuk C, Jiang CS, Hu X, Bhagavathi S, Greiner TC, Weisenburger DD, Aoun P, Perkins SL, McKeithan TW, Inghirami G, Chan WC (2013) MicroRNA expression profiling identifies molecular signatures associated with anaplastic large cell lymphoma. Blood 122:2083-2092

32. Brenner I, Roth S, Puppe B, Wobser M, Rosenwald A, Geissinger E (2013) Primary cutaneous marginal zone lymphomas with plasmacytic differentiation show frequent IgG4 expression. Mod Pathol 26:1568-1576

33. Mollejo M, Menárguez J, Guisado-Vasco P, Bento L, Algara $\mathrm{P}$, Montes-Moreno S, Rodriguez-Pinilla MS, Cruz MA, Casado F, Montalbán C, Piris MA (2013) Hepatitis C virus-related lymphoproliferative disorders encompass a broader clinical and morphological spectrum than previously recognized: a clinicopathological study. Mod Pathol. doi:10.1038/modpathol.2013.120

34. van den Brand M, van Krieken JH (2013) Recognizing nodal marginal zone lymphoma: recent advances and pitfalls. A systematic review. Haematologica 98:1003-1013

35. Adam P, Baumann R, Schmidt J, Bettio S, Weisel K, Bonzheim I, Fend F, Quintanilla-Martínez L (2013) The BCL2 E17 and SP66 antibodies discriminate immunophenotypically and genetically distinct subgroups of conventionally BCL2-"negative" grade $1 / 2$ follicular lymphomas. Hum Pathol 44:1817-1826

36. Schraders M, de Jong D, Kluin P, Groenen P, van Krieken H (2005) Lack of Bcl-2 expression in follicular lymphoma may be caused by mutations in the BCL2 gene or by absence of the $t(14 ; 18)$ translocation. J Pathol 205:329-335

37. Margolskee E, Jobanputra V, Lewis SK, Alobeid B, Green PH, Bhagat G (2013) Indolent small intestinal CD4+ T-cell lymphoma is a distinct entity with unique biologic and clinical features. PLoS One 8(7):e68343

38. Hayashi E, Takata K, Sato Y, Tashiro Y, Tachiyama Y, SawadaKitamura S, Hiramatsu Y, Sugiguchi S, Nose S, Hirokawa M, Ando M, Abd Alkader L, Maeda Y, Tanimoto M, Yoshino T (2013) Distinct morphologic, phenotypic, and clinical-course characteristics of indolent peripheral T-cell lymphoma. Hum Pathol 44: 1927-1936

39. Groenen PJ, Langerak AW, van Dongen JJ, van Krieken JH (2008) Pitfalls in TCR gene clonality testing: teaching cases. J Hematop 1: 97-109

40. Karai LJ, Kadin ME, Hsi ED, Sluzevich JC, Ketterling RP, Knudson RA, Feldman AL (2013) Chromosomal rearrangements of 6p25.3 define a new subtype of lymphomatoid papulosis. Am J Surg Pathol 37:1173-1181

41. Chang C, Huang SW, Su IJ, Chang KC (2013) Hematopathologic discrepancies between referral and review diagnoses: a gap between general pathologists and hematopathologists. Leuk Lymphoma [Epub ahead of print]. Available at: http://www.ncbi.nlm.nih.gov/ pubmed/23927394 
42. Strobbe L, van der Schans SA, Heijker S, Meijer JW, Mattijssen EJ, Mandigers CM, de Kievit IM, Raemaekers JM, Hebeda KM, van Krieken JH (2013) Evaluation of a panelof expert pathologists: review of the diagnosis and histological classification of Hodgkin and non-Hodgkin lymphomas in a population-based cancer registry. Leuk Lymphoma

43. Dyhdalo KS, Lanigan C, Tubbs RR, Cook JR (2013) Immunoarchitectural patterns of germinal center antigens including LMO2 assist in the differential diagnosis of marginal zone lymphoma vs follicular lymphoma. Am J Clin Pathol 140(2):149-154

44. Bob R, Falini B, Marafioti T, Paterson JC, Pileri S, Stein H (2013) Nodal reactive and neoplastic proliferation of monocytoid and marginal zone B cells: an immunoarchitectural and molecular study highlighting the relevance of IRTA1 and T-bet as positive markers. Histopathology. doi:10.1111/his.12160

45. Narayan G, Xie D, Freddy AJ, Ishdorj G, Do C, Satwani P, Liyanage H, Clark L, Kisselev S, Nandula SV, Scotto L, Alobeid B, Savage D, Tycko B, O'Connor OA, Bhagat G, Murty VV (2013) PCDH10 promoter hypermethylation is frequent in most histologic subtypes of mature lymphoid malignancies and occurs early in lymphomagenesis. Gene Chromosome Canc 52(11):1030-1041

46. Koh YW, Park C, Yoon DH, Suh C, Huh J (2013) Prognostic significance of COX-2 expression and correlation with Bcl-2 and VEGF expression, microvessel density, and clinical variables in classical Hodgkin lymphoma. Am J Surg Pathol 37:1242-1251

47. Navarro A, Muñoz C, Gaya A, Díaz-Beyá M, Gel B, Tejero R, Díaz T, Martinez A, Monzó M (2013) MiR-SNPs as markers of toxicity and clinical outcome in Hodgkin lymphoma patients. PLoS One 8(5): e64716. doi:10.1371/journal.pone.0064716

48. Wahlin BE, Sundström C, Sander B, Christensson B, JeppssonAhlberg A, Hjalmarsson E, Holte H, Ostenstad B, Brown PD, Smeland EB, Kimby E (2013) Higher World Health Organization grades of follicular lymphoma correlate with better outcome in two nordic lymphoma group trials of rituximab without chemotherapy. Leuk Lymphoma [Epub ahead of print] Available at: http://www. ncbi.nlm.nih.gov/pubmed/23662992

49. Maeshima AM, Taniguchi H, Nomoto J, Miyamoto K, Fukuhara S, Munakata W, Maruyama D, Kim SW, Watanabe T, Kobayashi Y, Tobinai K, Tsuda H (2013) Prognostic implications of histologic grade and intensity of Bcl-2 expression in follicular lymphomas undergoing rituximab-containing therapy. Hum Pathol 44(11):2529-2535

50. Hother C, Rasmussen PK, Joshi T, Reker D, Ralfkiær U, Workman CT, Heegaard S, Ralfkiær E, Grønbæk K (2013) MicroRNA profiling in ocular adnexal lymphoma: a role for MYC and NFKB1 mediated dysregulation of microRNA expression in aggressive disease. Invest Ophthalmol Vis Sci 54:5169-5175

51. Sánchez-Espiridión B, Martín-Moreno AM, Montalbán C, Figueroa V, Vega F, Younes A, Medeiros LJ, Alvés FJ, Canales M, Estévez M, Menarguez J, Sabín P, Ruiz Marcellán MC, Lopez A, SánchezGodoy P, Burgos F, Santonja C, López JL, Piris MA, Garcia JF (2013) MicroRNA signatures and treatment response in patients with advanced classical Hodgkin lymphoma. Br J Haematol 162:336347

52. Navarro A, Clot G, Prieto M, Royo C, Vegliante MC, Amador V, Hartmann E, Salaverria I, Beà S, Martín-Subero JI, Rosenwald A, Ott G, Wiestner A, Wilson WH, Campo E, Hernández L (2013) microRNA expression profiles identify subtypes of mantle cell lymphoma with different clinicobiological characteristics. Clin Cancer Res 19:3121-3129

53. Goswami RS, Atenafu EG, Xuan Y, Waldron L, Reis PP, Sun T, Datti A, Xu W, Kuruvilla J, Good DJ, Lai R, Church AJ, Lam WS, Baetz T, Lebrun DP, Sehn LH, Farinha P, Jurisica I, Bailey DJ, Gascoyne RD, Crump M, Kamel-Reid S (2013) MicroRNA signature obtained from the comparison of aggressive with indolent non-Hodgkin lymphomas: potential prognostic value in mantle-cell lymphoma. J Clin Oncol 31:2903-2911
54. Enjuanes A, Albero R, Clot G, Navarro A, Beà S, Pinyol M, Martín-Subero JI, Klapper W, Staudt LM, Jaffe ES, Rimsza L, Braziel RM, Delabie J, Cook JR, Tubbs RR, Gascoyne R, Connors JM, Weisenburger DD, Greiner TC, Chan WC, LópezGuillermo A, Rosenwald A, Ott G, Campo E, Jares P (2013) Genome-wide methylation analyses identify a subset of mantle cell lymphoma with a high number of methylated CpGs and aggressive clinicopathological features. Int J Cancer 133:28522863

55. Tiemann M, Schrader C, Klapper W, Dreyling MH, Campo E, Norton A, Berger F, Kluin P, Ott G, Pileri S, Pedrinis E, Feller AC, Merz H, Janssen D, Hansmann ML, Krieken H, Möller P, Stein H, Unterhalt M, Hiddemann W, Parwaresch R, European MCL Network (2005) Histopathology, cell proliferation indices and clinical outcome in 304 patients with mantle cell lymphoma (MCL): a clinicopathological study from the European MCL Network. Br J Haematol 131: 29-38

56. Klapper W, Hoster E, Determann O, Oschlies I, van der Laak J, Berger F, Bernd HW, Cabeçadas J, Campo E, Cogliatti S, Hansmann ML, Kluin PM, Kodet R, Krivolapov YA, Loddenkemper C, Stein H, Möller P, Barth TE, Müller-Hermelink K, Rosenwald A, Ott G, Pileri S, Ralfkiaer E, Rymkiewicz G, van Krieken $\mathrm{JH}$, Wacker $\mathrm{HH}$, Unterhalt M, Hiddemann W, Dreyling M, European MCL Network (2009) Ki-67 as a prognostic marker in mantle cell lymphoma-consensus guidelines of the pathology panel of the European MCL Network. J Hematop 2:103-111

57. Benton EC, Crichton S, Talpur R, Agar NS, Fields PA, Wedgeworth E, Mitchell TJ, Cox M, Ferreira S, Liu P, Robson A, Calonje E, Stefanato CM, Wilkins B, Scarisbrick J, Wain EM, Child F, Morris S, Duvic M, Whittaker SJ (2013) A cutaneous lymphoma international prognostic index (CLIPi) for mycosis fungoides and Sezary syndrome. Eur J Cancer 49:2859-2868

58. Khan AB, Barrington SF, Mikhaeel NG, Hunt AA, Cameron L, Morris T, Carr R (2013) PET-CT staging of DLBCL accurately identifies and provides new insight into the clinical significance of bone marrow involvement. Blood 122(1):61-67

59. Cortés-Romera M, Sabaté-Llobera A, Mercadal-Vilchez S, ClimentEsteller F, Serrano-Maestro A, Gámez-Cenzano C, González-Barca E (2014) Bone marrow evaluation in initial staging of lymphoma: $18 \mathrm{~F}$ FDG PET/CT versus bone marrow biopsy. Clin Nucl Med 39(1): e46-e 52

60. Berthet L, Cochet A, Kanoun S, Berriolo-Riedinger A, Humbert O, Toubeau M, Dygai-Cochet I, Legouge C, Casasnovas O, Brunotte F (2013) In newly diagnosed diffuse large B-cell lymphoma, determination of bone marrow involvement with $18 \mathrm{~F}-\mathrm{FDG}$ PET/CT provides better diagnostic performance and prognostic stratification than does biopsy. J Nucl Med 54(8):1244-1250

61. Moon SH, Cho SK, Kim WS, Kim SJ, Chan Ahn Y, Choe YS, Lee KH, Kim BT, Choi JY (2013) The role of 18F-FDG PET/CT for initial staging of nasal type natural killer/T-cell lymphoma: a comparison with conventional staging methods. J Nucl Med 54(7):10391044

62. Muñoz-Mármol AM, Sanz C, Tapia G, Marginet R, Ariza A, Mate JL (2013) MYC status determination in aggressive B-cell lymphoma: the impact of FISH probe selection. Histopathology 63:418-424

63. Oberley MJ, Rajguru SA, Zhang C, Kim K, Shaw GR, Grindle KM, Kahl BS, Kanugh C, Laffin J, Yang DT (2013). Immunohistochemical evaluation of MYC expression in mantle cell lymphoma. Histopathology. doi: 10.1111/his.12207. [Epub ahead of print] Available at: http://www.ncbi.nlm.nih.gov/pubmed/23926923

64. van Krieken JH, Langerak AW, Macintyre EA, Kneba M, Hodges E, Sanz RG, Morgan GJ, Parreira A, Molina TJ, Cabeçadas J, Gaulard P, Jasani B, Garcia JF, Ott M, Hansmann ML, Berger F, Hummel M, Davi F, Brüggemann M, Lavender FL, Schuuring E, Evans PA, White H, Salles G, Groenen PJ, Gameiro P, Pott C, Dongen JJ 
(2007) Improved reliability of lymphoma diagnostics via PCR-based clonality testing: report of the BIOMED-2 Concerted Action BHM4CT98-3936. Leukemia 21:201-206

65. Langerak AW, Molina TJ, Lavender FL, Pearson D, Flohr T, Sambade C, Schuuring E, Al Saati T, van Dongen JJ, van Krieken JH (2007) Polymerase chain reaction-based clonality testing in tissue samples with reactive lymphoproliferations: usefulness and pitfalls. A report of the BIOMED-2 Concerted Action BMH4-CT98-3936. Leukemia 21:222-229

66. van Dongen JJ, Langerak AW, Brüggemann M, Evans PA, Hummel M, Lavender FL, Delabesse E, Davi F, Schuuring E, García-Sanz R, van Krieken JH, Droese J, González D, Bastard C, White HE, Spaargaren M, González M, Parreira A, Smith JL, Morgan GJ, Kneba M, Macintyre EA (2003) Design and standardization of PCR primers and protocols for detection of clonal immunoglobulin and T-cell receptor gene recombinations in suspect lymphoproliferations: report of the BIOMED-2 Concerted Action BMH4-CT98-3936. Leukemia 17:2257-2317

67. Hartmann S, Helling A, Döring C, Renné C, Hansmann ML (2013) Clonality testing of malignant lymphomas with the BIOMED-2 primers in a large cohort of 1969 primary and consultant biopsies. Pathol Res Pract 209:495-502

68. Geurts-Giele WR, Wolvers-Tettero IL, Dinjens WN, Lam KH, Langerak AW (2013) Successive B-cell lymphomas mostly reflect recurrences rather than unrelated primary lymphomas. Am J Clin Pathol 140:114-126

69. West DS, Dogan A, Quint PS, Tricker-Klar ML, Porcher JC, Ketterling RP, Law ME, McPhail ED, Viswanatha DS, Kurtin PJ, Dao LN, Ritzer RD, Nowakowski GS, Feldman AL (2013) Clonally related follicular lymphomas and Langerhans cell neoplasms: expanding the spectrum of transdifferentiation. Am J Surg Pathol 37:978-986 